\title{
Validity of the Cottid Species Stelgistrum mororane Transferred to the Genus Icelus (Actinopterygii: Perciformes: Cottoidei), with Confirmed Records of Stelgistrum stejnegeri from Japanese Waters
}

\author{
Osamu Tsuruoka ${ }^{1}$, Takuzo Abe ${ }^{2}$ and Mamoru Yabe ${ }^{3}$ \\ ${ }^{1}$ Laboratory of Marine Biodiversity (Systematic Ichthyology), Graduate School of \\ Fisheries Sciences, Hokkaido University, Hakodate, 041-8611 Japan \\ Present address: Hokkaido Hakodate Fisheries High School, \\ 2-15-3 Nanaehama, Hokuto, 049-0111 Japan \\ E-mail: tsuru357@gmail.com \\ ${ }^{2}$ Shizugawa Nature Center, 40 Sakamoto, Minamisanriku-cho Togura, \\ Motoyoshi-gun, Miyagi, 986-0781 Japan \\ Present address: Faculty of Fisheries Science, Hokkaido University, \\ Hakodate, 041-8611 Japan \\ E-mail:takuzo@oshoroken.fish.hokudai.ac.jp \\ ${ }^{3}$ Laboratory of Marine Biology and Biodiversity (Systematic Ichthyology), \\ Research Faculty of Fisheries Sciences, Hokkaido University, \\ Hakodate, 041-8611 Japan \\ E-mail:myabe@fish.hokudai.ac.jp
}

(Received 25 July 2008; Accepted 26 December 2008)

\begin{abstract}
Stelgistrum mororane Jordan and Seale, 1906, previously synonymized with Stelgistrum stejnegeri Jordan and Gilbert, 1898, is here redescribed as a valid species of the genus Icelus. Contrary to the original description, the holotype of S. mororane has palatine teeth, which are diagnostic of Icelus but absent in Stelgistrum. Icelus mororanis comb. nov. is distinguished from all other species of Icelus by the following combination of characters: body relatively short; parietal spine undeveloped; subocular and supraocular spines absent; scales absent on cheek, between dorsal scale row and lateral line, and below lateral line except at pectoral axilla; small and simple cirrus present on upper rim of eye; two pairs of nuchal cirri present; and four saddles present on dorsolateral surface of body. Additionally, seven specimens of Stelgistrum stejnegeri collected from the Pacific coast of eastern Hokkaido are described, representing the first confirmed records of this species in Japanese waters.
\end{abstract}

Key Words: Redescription, Icelus mororanis comb. nov., Stelgistrum stejnegeri, confirmed record, Japan.

\section{Introduction}

The cottid genus Stelgistrum Jordan and Gilbert, 1898 is characterized by having four preopercular spines, teeth present on the jaws and vomer but absent on the palatines, one scale row on the lateral line and another scale row along the dor- 
sal-fin base, a single pharyngeal tooth plate, no urogenital papilla, and a pelvic fin with one spine and three soft rays (Andriashev 1935). Three species are currently recognized as valid in this genus: S. stejnegeri Jordan and Gilbert, 1898, S. beringianum Gilbert and Burke, 1912, and S. concinnum Andriashev, 1935. All are distributed in the northern North Pacific, Bering Sea, Sea of Okhotsk, and northern Sea of Japan.

In addition to those three species, Stelgistrum mororane Jordan and Seale, 1906, was described on the basis of a single specimen collected from off Muroran (spelled "Mororan" in the original description), Volcano Bay, Hokkaido, Japan. Jordan et al. (1913), however, regarded $S$. mororane as a junior synonym of S. stejnegeri without discussion. Andriashev (1935) indicated that $S$. mororane differed from $S$. stejnegeri in the counts of anal-fin rays and the existence of a granulation (dermal cirrus) on the dorsal surface of the head, but he nevertheless supported the opinion of Jordan et al. (1913). Other authors followed these decisions and considered $S$. mororane as a junior synonym of $S$. stejnegeri (e.g., Watanabe 1958, 1960, 1978; Lindberg and Krasyukova 1987).

Recently, a large number of small cottid specimens were collected from the shallow marine waters of northern Japan, including near Muroran, the type locality of $S$. mororane. These specimens greatly resemble $S$. mororane or S. stejnegeri, but clearly belong to the genus Icelus Krøyer, 1845 on account of their having teeth on the palatines (Nelson 1984; Yabe 1985). Jordan and Seale (1906) originally described $S$. mororane as having no teeth on the palatines, but our reexamination of the holotype confirmed that $S$. mororane does have some teeth there. Therefore, $S$. mororane must be placed in the genus Icelus and is distinct from S. stejnegeri.

In this study, we redescribe Icelus mororanis on the basis of 103 specimens including the holotype and additional non-type specimens. Additionally, we redescribe Stelgistrum stejnegeri based on seven specimens newly collected from eastern Hokkaido, Japan, because the previous records of this species from Japanese waters are imprecise and unconfirmable.

\section{Materials and Methods}

The methods used for taking counts and measurements follow Hubbs and Lagler (1958) and Yabe (1991) except that interdorsal width was measured between the base of the last spine of the first dorsal fin and the origin of the second dorsal fin. Total length (TL), standard length (SL), and head length (HL) are used throughout unless indicated otherwise. All fin-ray elements were counted. Vertebrae and caudal-fin rays were observed and counted from radiographs. Sex was determined by observation of the gonads. The higher classification of the family Cottidae follows that presented by Imamura and Yabe (2002). Symbolic codes for institutions are those provided by Eschmeyer (1998). All materials examined in this study are given in the appendix. 


\section{Taxonomy}

Icelus mororanis (Jordan and Seale, 1906) comb. nov.

[New Japanese name: Usujiri-kajika]

(Figs 1, 2, Tables 1, 2)

Stelgistrum mororane Jordan and Seale, 1906: 146, fig. 4 [original description, holotype, sex unknown (31.8 mm TL), in harbor at Mororan (=Muroran), Hokkaido, Japan]; Böhlke 1953: 132 (listed, type specimen in SU); Eschmeyer 1998: 1122 (validity).

Stelgistrum mororanae [sic]: Andriashev 1935: 296-297 (description, distribution, synonymy).

Stelgistrum stejnegeri (not Jordan and Gilbert, 1898): Jordan et al. 1913: 258, fig. 195 (in part, listed, Japan, distribution); Watanabe 1958: 14, 227-230, figs 77, 78, pls 5 (lower), 56 (in part, listed, Japan, diagnosis, description of internal features); 1960: 32-35, fig. 11, pl. 20 (fig. 2) (in part, description); 1976: 6 (in part, listed, Japan); 1978: 230-232, figs 77, 78, pl. 19 (second from top) (in part, description); 1980: 427-428, pl. 48 (description of osteological features); 1981: 106 (in part, description of quantitative features); Lindberg and Krasyukova 1987: 195-196 (in part?, diagnosis, distribution).

Material examined. 103 specimens (24.0-44.7 mm SL) including holotype of Stelgistrum mororane (see Appendix).

Diagnosis. A species of the genus Icelus having the following combination of characters: subocular, supraocular, parietal, and nuchal spines absent; uppermost preopercular spine unbranched; single dorsal scale row; scales of lateral line and dorsal rows with serrated margins; no scales on cheek, between dorsal scale row and lateral line, nor below lateral line except for pectoral axilla, where small scales sometimes present; small, unbranched cirrus on upper rim of eye; one pair each of supraocular and parietal cirri, and two pairs of nuchal cirri; four saddles on dorsolateral surface of body; soft rays of second dorsal fin 14-17; anal-fin rays 10-13; pectoral-fin rays $15-16$; vertebrae $12+23-25=35-37$.

Description. Proportional measurements and counts are given in Tables 1 and 2. In the following text, data for the holotype are shown first, followed by data for non-type specimens in parentheses.

Body short, compressed (Fig. 1), body depth at origin of first dorsal fin 1.25 (1.00-1.67) times body width. Head (Fig. 2) large, slightly compressed, length $41.7 \%$ $(37.0-43.5 \%)$ of SL, depth at base of uppermost preopercular spine $1.25(0.83-1.25)$ times head width. Caudal peduncle slender, compressed, depth $27.0 \%(23.8-37.0 \%)$ of its length. Upper profile of snout steep, length $25.6 \%(23.3-31.3 \%)$ of HL. Nasal spine short, sharp, directed posterodorsally. Anterior nostril on outer base of nasal spine, forming short tube. Posterior nostril on anterior margin of orbit, with low rim. Mouth large; lower jaw extending foward slightly beyond upper jaw. Maxilla extending to level of posterior margin of orbit. Small conical teeth on jaws, vomer, and palatines (palatines partly broken in holotype). Eye large, length of orbit $29.4 \%$ $(25.0-34.5 \%)$ of HL. Interorbital space narrow, concave, width $25.6 \%(20.8-37.0 \%)$ of orbit length. Occipital region slightly concave, without knob or ridge. Four preopercular spines: uppermost spine unbranched, sharp, hooked posterodorsally; sec- 


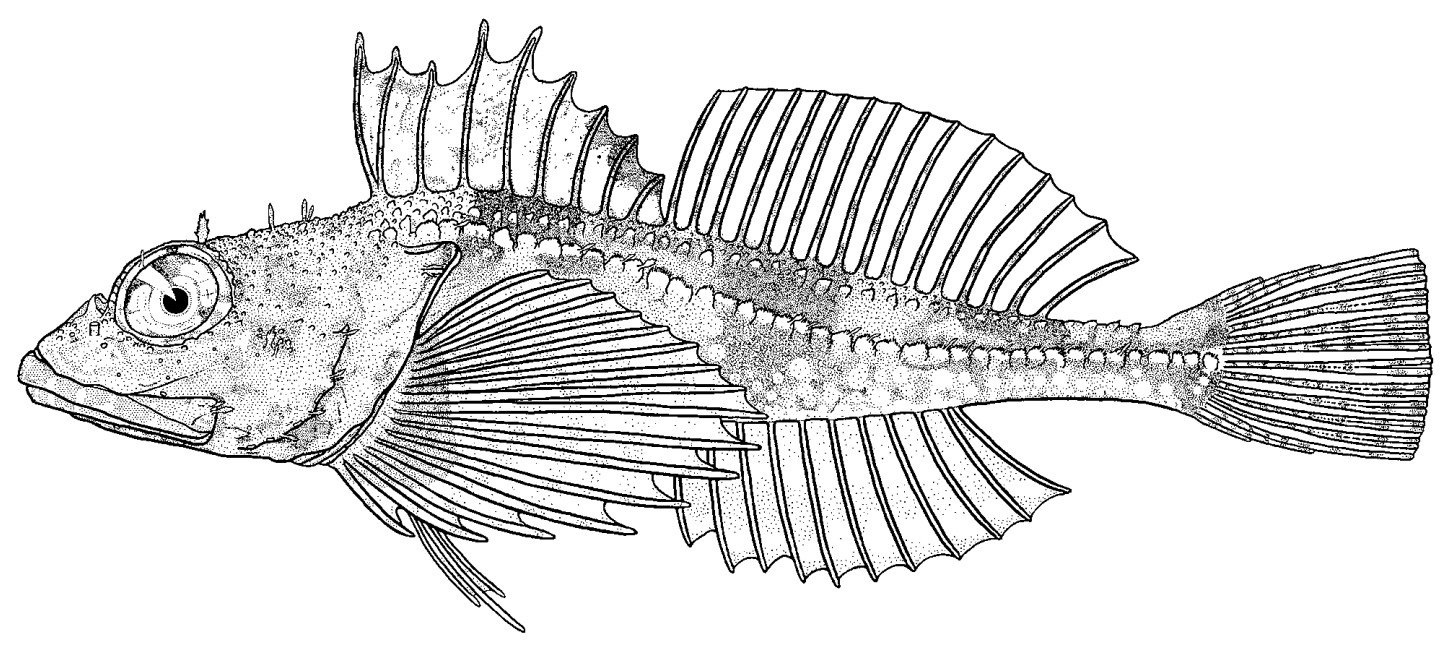

Fig. 1. Icelus mororanis (Jordan and Seale, 1906) comb. nov., HUMZ 189781, male, $37.8 \mathrm{~mm} \mathrm{SL}$, collected from off Usujiri, Hakodate.

ond spine slightly blunted, directed posteriorly; third spine also slightly blunted, directed ventrally; lowermost spine small, directed anteroventrally, buried under skin. Numerous small scales scattered around orbit and on base of nasal spine, upper rim of eye, and dorsolateral surface of head above suborbital stay. Both jaws and ventral surface of head naked. Lateral line descending posteriorly in slight arch from upper border of supracleithrum to level of seventh or eighth (broken in holotype) ray of anal fin, then running directly posteriad along body axis. Scales on lateral line large, tubular, with serrated margins dorsally and posteriorly. Midsized scales with serrated dorsal margins arranged along dorsal-fin base, to form dorsal scale row originating beneath base of second spine of first dorsal fin and extending to caudal peduncle. Small scales with serrated margins scattered above dorsal scale row and on spines and soft rays of dorsal fin. No scales between dorsal scale row and lateral line, nor below lateral line. No (no or some small) ctenoid scales scattered in pectoral axilla. Belly naked. Four pairs of cirri on dorsal surface of head: pair of supraocular cirri developed as narrowly based dermal flaps bearing numerous short appendages along distal margin; pair of parietal cirri with short appendages along distal margins; and two pairs of small, unbranched nuchal cirri (Fig. 2). No cirri on base of nasal spine. One simple cirrus on dorsal margin of eye. One (one or two) simple cirrus on posterior end of maxilla. Two cirri on suborbital stay and posterior region of opercle, i.e., small cirrus with branched tip and small, simple cirrus, respectively. One or two small, simple cirri on base of each preopercular spine. Single cirrus present on several lateral-line scales.

First dorsal fin originating at level of posterior margin of opercular flap. First and second dorsal fins joined by low fin-membrane. Basal length of first dorsal fin $66.7 \%(52.6-83.3 \%)$ of that of second dorsal fin. Second dorsal fin originating above 13th (11th-13th) lateral-line scale. Anal fin originating at level of origin of second dorsal fin, its basal length $83.3 \%(58.8-83.3 \%)$ of that of second dorsal fin. Pectoral fin large, length $22.7-34.5 \%$ of SL (broken in holotype), with rounded posterior margin; base of uppermost ray beneath second (second or third) lateral-line scale; eighth or ninth ray longest (broken in holotype), extending posteriorly to level of 


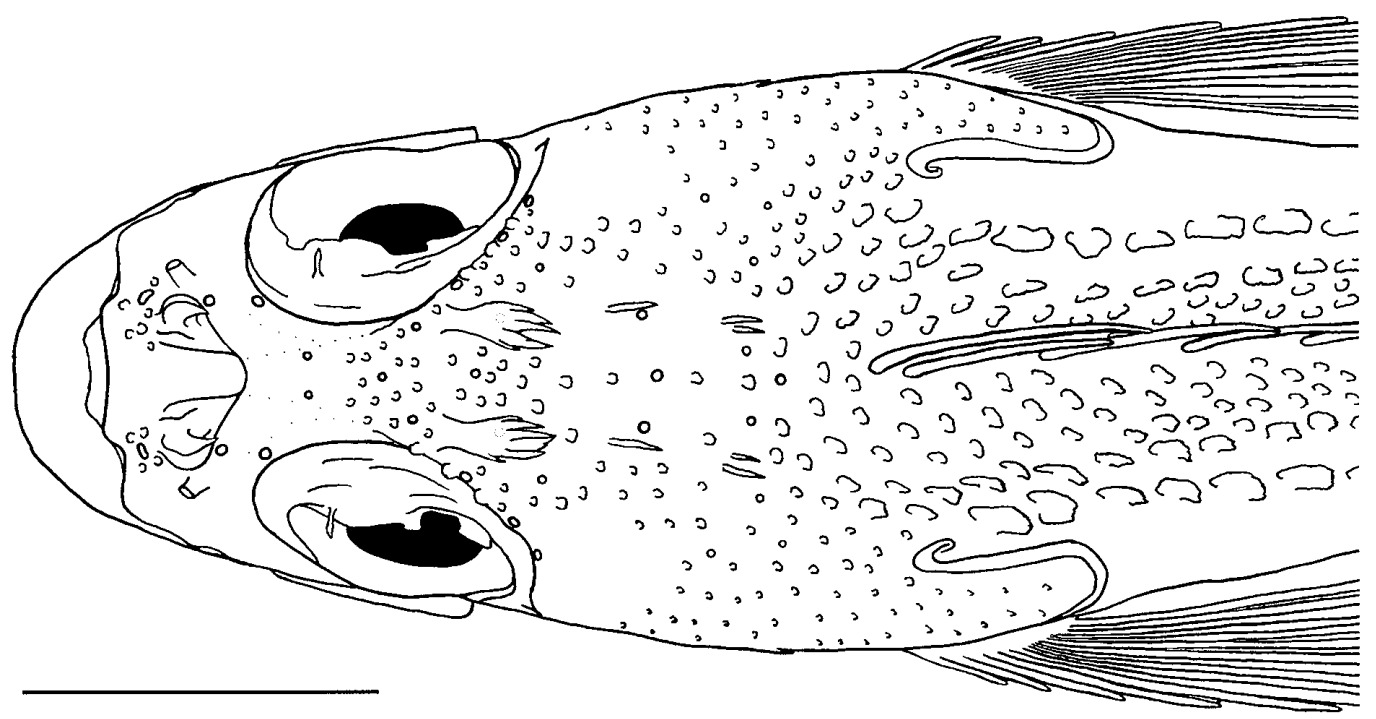

Fig. 2. Dorsal view of head of Icelus mororanis (Jordan and Seale 1906) comb. nov., HUMZ 189781. Scale bar $5 \mathrm{~mm}$.

fourth or fifth ray of second dorsal fin (broken in holotype); lower six (six or seven) rays slightly thickened. Pelvic fin slender, originating beneath second spine of first dorsal fin; middle ray longest; spine and outermost soft ray closely united. Caudal fin slightly rounded posteriorly; 11 rays supported by hypural plates, uppermost and lowermost two rays unbranched, middle seven rays branched; five (five to eight) upper and four (four to seven) lower procurrent rays. Anus located below eighth spine of first dorsal fin. Males lacking urogenital papilla.

Color in alcohol. Body light brown (light brown or grayish brown), with four dark saddles dorsolaterally; area below lateral line, except for pectoral axilla and belly, light brown (light brown or grayish brown) with numerous pale spots. Head darker than body; occipital and suborbital regions especially dark. First dorsal fin transparent with large dark blotch on posterior margin. Second dorsal fin transparent with obscure oblique dark stripes. Pectoral fin translucent with triangular dark blotch on base, some small dark blotches on each ray. Pelvic fin pale with slightly darker base. Anal fin transparent with dark stripes. Caudal fin pale with some dark lateral stripes.

Color when fresh (based on non-type materials). Ground color of body creamwhite, grayish brown, or reddish brown; pectoral axilla and ventral surface of body whitish. Four dark brown saddles across back: one below middle part of first dorsal fin, two below second dorsal fin, and one on caudal peduncle. Head below suborbital deep brown. Some vertical brown stripes on upper jaw. Ground color of first dorsal fin transparent, bearing brown vermiculations; black blotch on posterior margin. Second dorsal fin transparent, bearing obscure oblique brown stripes. Black triangular blotch on base of pectoral fin. Pelvic fin white, with slightly darker spots on base. Anal fin transparent, with two or three dark brown horizontal stripes (discolored in holotype). Caudal fin transparent, with reddish-brown lateral stripes. Cirri darkly pigmented except for those on lateral-line scales.

Distribution. Off Muroran, Volcano Bay, Hokkaido (Jordan and Seale 1906). 


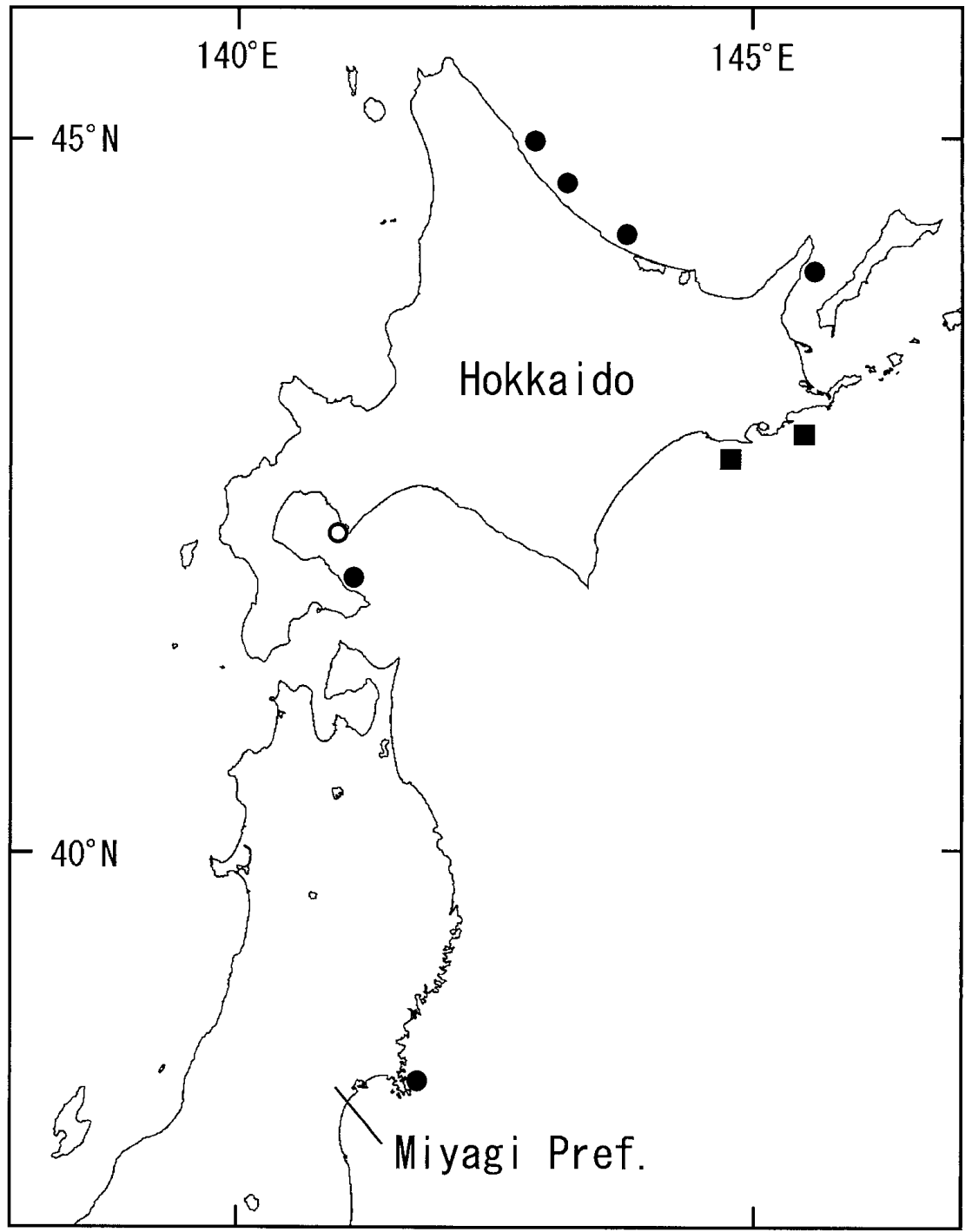

Fig. 3. Collection sites of the specimens used in this study. Holotype (open circle) and nontype specimens (solid circles) of Icelus mororanis (Jordan and Seale, 1906) comb. nov. and non-type specimens (solid squares) of Stelgistrum stejnegeri Jordan and Gilbert, 1898.

Off Esashi, Oumu, and Monbetsu, Okhotsk coast of Hokkaido; off Rausu on Shiretoko Peninsula, eastern Hokkaido; off Usujiri on Oshima Peninsula, southern Hokkaido; and off Miyagi Prefecture, Pacific coast of Honshu, Japan (Fig. 3) (this study). Rocky and/or boulder-stone areas in depths of 5-100 m.

Comparison. According to Yabe (1985), Icelus and Stelgistrum form a multiplebranching monophyletic group with Ricuzenius, Thyriscus, Stlengis, and Icelinus supported by a single synapomorphy: absence of the second and fourth pharyngobranchial bones. Icelus and Stelgistrum are very similar to each other in their external appearance (e.g., one dorsal scale row and one lateral-line scale row on body, pelvic fin composed of one spine and three soft rays), although they can be separated clearly by the presence (in Icelus) or absence (in Stelgistrum) of teeth on the palatines (e.g., Jordan and Gilbert 1898; Watanabe 1958, 1960; Yabe 1985; Lindberg 
and Krasyukova 1987). Although Jordan and Seale (1906) originally described Stelgistrum mororane as having no teeth on the palatines, the holotype of $S$. mororane has a few teeth on its palatines; therefore, this species should be regarded as a member of the genus Icelus rather than the genus Stelgistrum.

As was mentioned above, Icelus mororanis differs from Stelgistrum stejnegeri in having palatine teeth and, moreover, it can be distinguished also in having no scales on the cheek (vs small, scattered scales in S. stejnegeri). Additionally, differences in the number of second dorsal-fin rays, anal-fin rays, and lateral-line scales between Icelus mororanis and Stelgistrum stejnegeri are statistically significant (Mann-Whitney $U$ test; $P<0.01$ ) (Table 2).

Although Andriashev (1935) noted that a granulation (dermal cirrus) on the dorsal surface of head was present in the original drawing of $S$. mororane but not in that of $S$. stejnegeri, this feature is actually present in both species, including the holotype of each, and does not provide a way to distinguish them.

Currently, 17 species are recognized in the genus Icelus (Yabe 1983; Nelson 1984; Tsutsui and Yabe 1996; Nakabo 2000; Tsuruoka et al. 2006). Icelus mororanis differs from all species of Icelus, except for I. gilberti Taranetz, 1936 and I. sekii Tsuruoka, Munehara and Yabe, 2006, in having the following combination of characters: body slightly short, not elongated (body depth at first dorsal fin origin more than $18.5 \%$ of SL); nuchal spine obscure; supraocular and parietal spines absent; uppermost preopercular spine simple, not bifid; and body color light or grayish brown in alcohol. Icelus mororanis is distinguished from I. sekii in having two pairs of nuchal cirri (one pair in I. sekii) and four saddles on the dorsolateral surface of the body (five saddles). Icelus mororanis differs from $I$. gilberti in having no scales on the cheek (small, scattered scales in Icelus gilberti), no scales between the dorsal scale row and the scale row on the lateral line (several scales present in that area), two pairs of nuchal cirri (one pair), and a relatively short anal-fin base $(18.2-25.3 \%$ of SL vs $27.0-30.1 \%$ of SL; Table 1$)$. In addition, the number of rays of the second dorsal fin and anal fin, and the number of lateral-line scales, are also valuable to distinguish $I$. mororanis from $I$. gilberti and $I$. sekii, although the counts partially overlap: $I$. mororanis has $14-17$ (mode 16 ) rays in the second dorsal fin, 10-13 (11) rays in the anal fin, and 35-39 (37) scales in the lateral line; I. gilberti has respectively 17-18 (17, 18), 12-13 (13), and 38-39 (39); and $I$. sekii has respectively 17-19 (18), 12-14 (13), and 38-40 (39) (Table 2). These differences are statistically significant (Kruskal-Wallis test and Steel's procedure; $P<0.01$ between $I$. mororanis and the other two species).

Icelus sekii has previously been known as the smallest species (maximum of $53.3 \mathrm{~mm} \mathrm{SL}$ ) in this genus, but I. mororanis is even smaller [maximum of $44.7 \mathrm{~mm}$ SL (HUMZ 187866)] and matures at the smallest size among the species of the genus.

Although the presence (in Icelus) or absence (in Stelgistrum) of teeth on the palatines is the only diagnostic character separating the two genera, Matsubara (1955) noted in his key to genera that Stelgistrum (and/or Astrocottus) occasionally has a few teeth on the palatines. Further studies aimed at clarifying the interrelationships and validity of Icelus and Stelgistrum are needed.

Remarks. In the serial studies of Japanese cottoids by Watanabe (1958, 1960, 1976, 1978, 1980, 1981), a few specimens of Stelgistrum stejnegeri were used as the basis for his description. The management of part of Watanabe's collection has 
been entrusted to NSMT, but these specimens have not been found there (G. Shinohara pers. comm.). The following remarks are thus based wholly on Watanabe's papers cited here, since no reexamination of the material has been possible. Watanabe (1980) described the internal features of $S$. stejnegeri based on one specimen, no. 20147, which is reidentified herein as $I$. mororanis because palatine teeth were illustrated in the drawings (Watanabe 1980, pl. 48). This specimen can be traced back through his earlier works. Watanabe (1978) described the external features of S. stejnegeri on the basis of two specimens, nos 20146 and 20147, of which the latter at least is $I$. mororanis, as was shown above. Watanabe (1960) used the two same specimens, according to that work's supplement (Watanabe 1981). The description of the external features of $S$. stejnegeri provided by Watanabe (1958) was based on one specimen, w. 21882, and the descriptions of the internal features and quantitative characters were based on two uncatalogued specimens. These uncatalogued specimens were evidently the same as nos 20146 and 20147 used in Watanabe $(1978,1980,1981)$, because the counts and measurements given in the tables, figures, and plates of each study are much the same (cf. Watanabe 1958, table 55 , figs 77 , 78. vs Watanabe 1978, table 55 , figs 77 , 78; Watanabe 1958, pl. 56 vs Watanabe 1980, pl. 48), and Watanabe's (1958) description must, therefore, also have been partly based on at least one specimen of $I$. mororanis. Watanabe (1976) presented only S. stejnegeri in his species list of the Cottoidei of Japan, but it would be appropriate to consider that the specimens involved included both $I$. mororanis and S. stejnegeri.

Lindberg and Krasyukova (1987) redescribed S. stejnegeri on the basis of 30 specimens collected from the Sea of Okhotsk and the Sea of Japan, but some specimens of $I$. mororanis are likely to have been mixed in with them, because the reported number of dorsal-fin spines was 8-10, and dorsal scales 35-38 (I. mororanis has 8-10 dorsal-fin spines and 25-38 dorsal scales, and S. stejnegeri, 9-10 dorsal-fin spines and 29-36 dorsal scales; this study).

Although no collection of $I$. mororanis has been reported until now since its original description, it is likely to be widely distributed around the coast of northern Japan. The many specimens found in various collections and our own observations while SCUBA diving demonstrate its occurrence at least from the Okhotsk coast of Hokkaido to the Pacific coast of Miyagi Prefecture, Japan.

Stelgistrum stejnegeri Jordan and Gilbert, 1898

[English name: Furseal sculpin]

[Japanese name: Ottosei-kajika]

(Fig. 4, Tables 1, 2)

Stelgistrum stejnegeri Jordan and Gilbert, 1898: 1921 [original description, holotype, sex unknown (52 mm TL), off Robben Island (=Ostrov Tyuleniy), Sea of Okhotsk off southern part of Sakhalin, Russia]; Jordan and Starks 1904: 248, fig. 7 [description, following Jordan and Gilbert (1899)]; Schmidt 1904: 117 (diagnosis); Jordan et al. 1913: 258, fig. 195 (in part, listed, Japan, distribution); Popov 1931: 128-129 (diagnosis); Tanaka 1933: 263 (short comments on fisheries); Okada and Matsubara 1938: 321 (key); Matsubara 1955: 1140 (key); Watanabe 1958: 14, 227-230, figs 77, 78, pls 5 (lower), 56 (in part, listed, Japan, di- 
agnosis, description of internal features); 1960: 32-35, fig. 11, pl. 20 (fig. 2) (in part, description); Ueno 1971: 91 (listed, Hokkaido and adjacent waters); Watanabe 1976: 6 (in part, listed, Japan); 1978: 230-232, figs 77, 78, pl. 19 (second from top) (in part, description); 1981: 106 (in part, description of quantitative features); Yabe 1984: 310 (diagnosis, distribution); 1985: 4 (material for phylogenetic analysis of the superfamily Cottoidea); Nakabo 1993: 555 (key); Eschmeyer 1998: 1606 (validity); Nakabo 2000: 636 (key); Sheiko and Fedorov 2000: 29 (listed, Kamchatka and adjacent waters); Mecklenberg et al. 2002: 447 (diagnosis, distribution); Nakabo 2002: 636 (key); Parin et al. 2002: 86 (listed, Russia and adjacent countries, distribution); Fedorov et al. 2003: 80 (distribution).

Stelgistrum steinegeri [sic]: Jordan and Gilbert 1899: 456, pl. 54 (description); Soldatov and Lindberg 1930: 182-183 (in part, diagnosis, synonymy, distribution); Popov 1933: 144 (listed, Sea of Japan); Andriashev 1935: 294-297 (in part, description, distribution, synonymy); Taranetz 1937: 109 (key); 1941: 430 (discussion about Icelinae); Schmidt 1950: 127 (diagnosis, distribution); Lindberg and Krasyukova 1987: 195-196, fig. 121 (in part ?, diagnosis, distribution); Orlov 1998: 150 (listed, Pacific waters around Kuril Islands and southeastern Kamchatka); Sokolovskaya et al. 1998: 5 (listed, Peter the Great Bay).

Material examined. 7 specimens collected from Japanese waters (see Appendix).

Description. Proportional measurements and counts as given in Tables 1 and 2 .

Body short, compressed posteriorly (Fig. 4). Head large, slightly depressed. Caudal peduncle slender, compressed. Upper profile of snout steep. Nasal spine short, sharp. Mouth large; lower jaw extending forward slightly beyond upper jaw. Small teeth on jaws and vomer. No teeth on palatines. Interorbital space narrow, concave. Four preopercular spines: uppermost spine unbranched, sharp, hooked posterodorsally; lower three spines slightly blunt, directed posteriorly or ventrally. Numerous small scales scattered on fringe of nasal spine, interorbital space, suborbital region, outer rim of eye, cheek, and dorsolateral surface of head. Both jaws and ventral surface of head naked. Lateral line descending in slight arch anteriorly. Scales on lateral line large, tubular, with serrated margins dorsally and

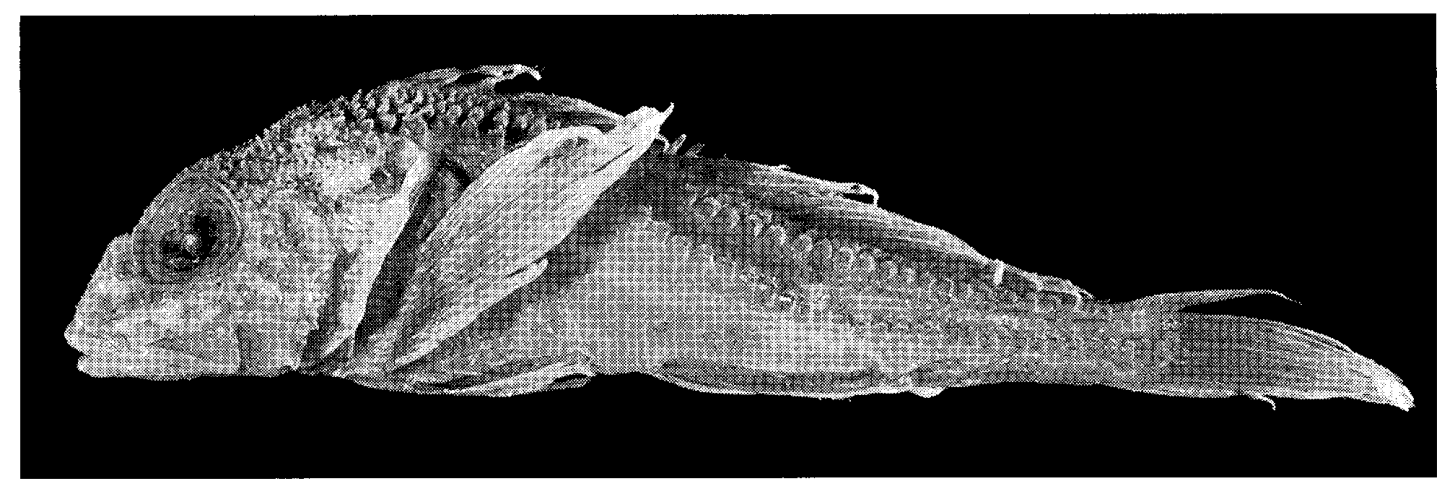

Fig. 4. Stelgistrum stejnegeri Jordan and Gilbert, 1898, HUMZ 92926, female, $44.2 \mathrm{~mm}$ SL, collected from off Hamanaka, Pacific coast of Hokkaido. 


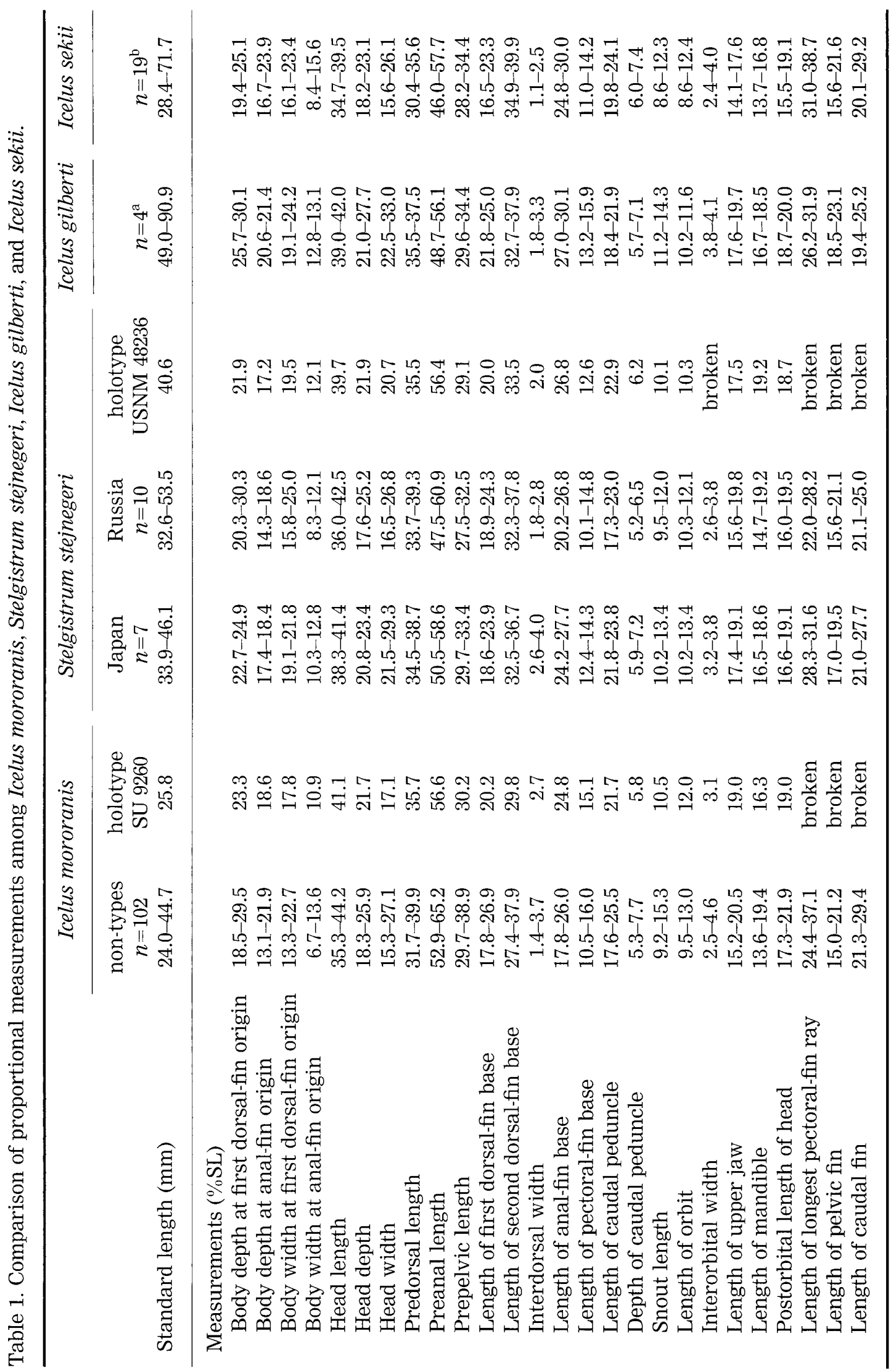




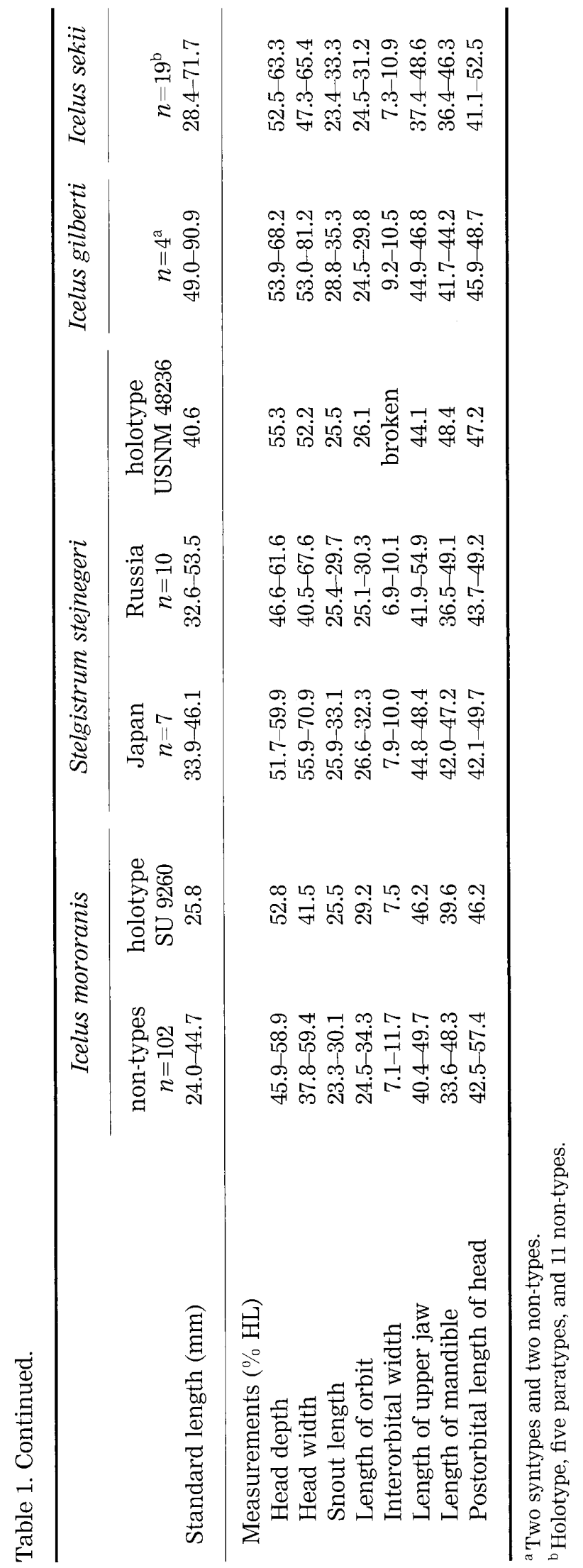




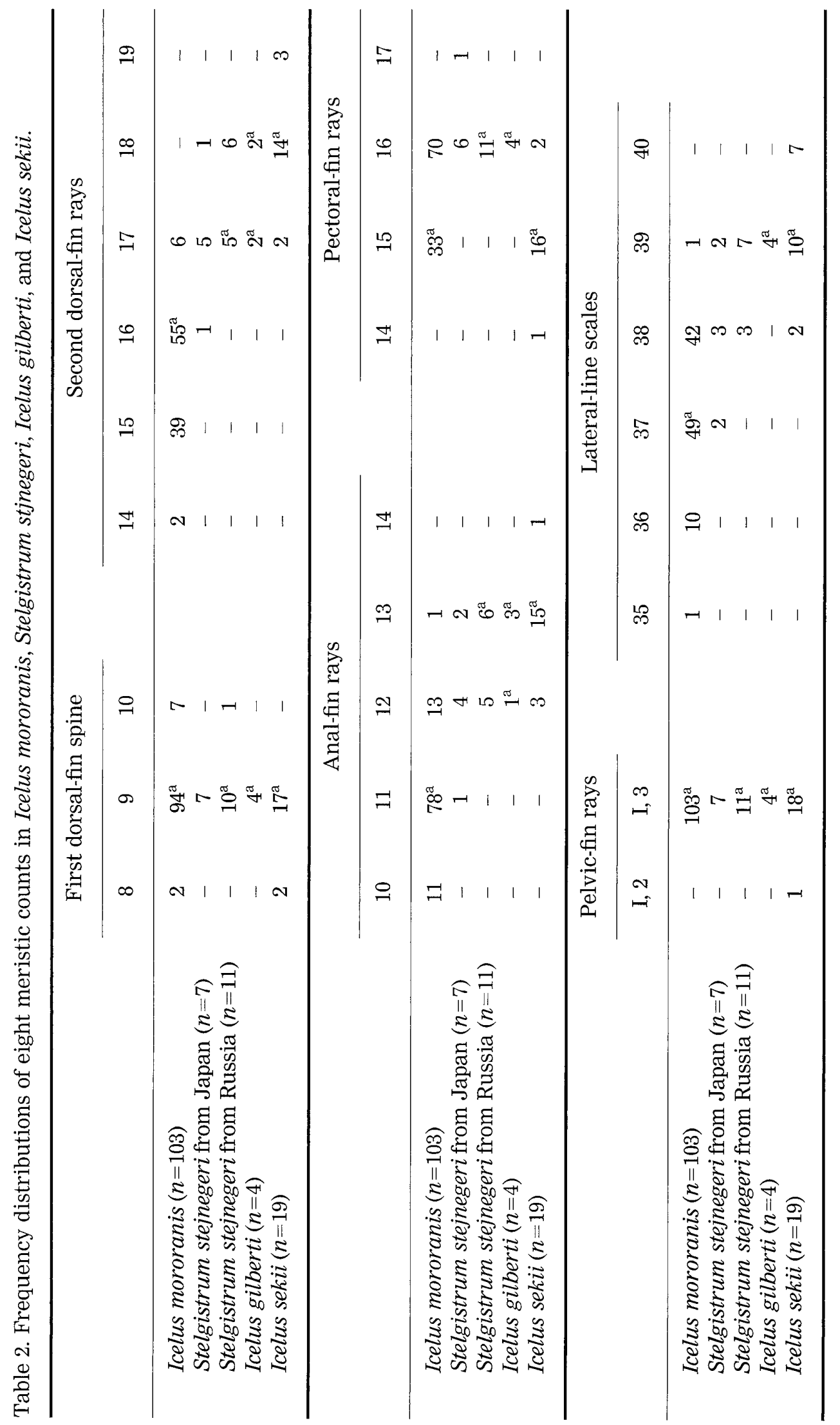




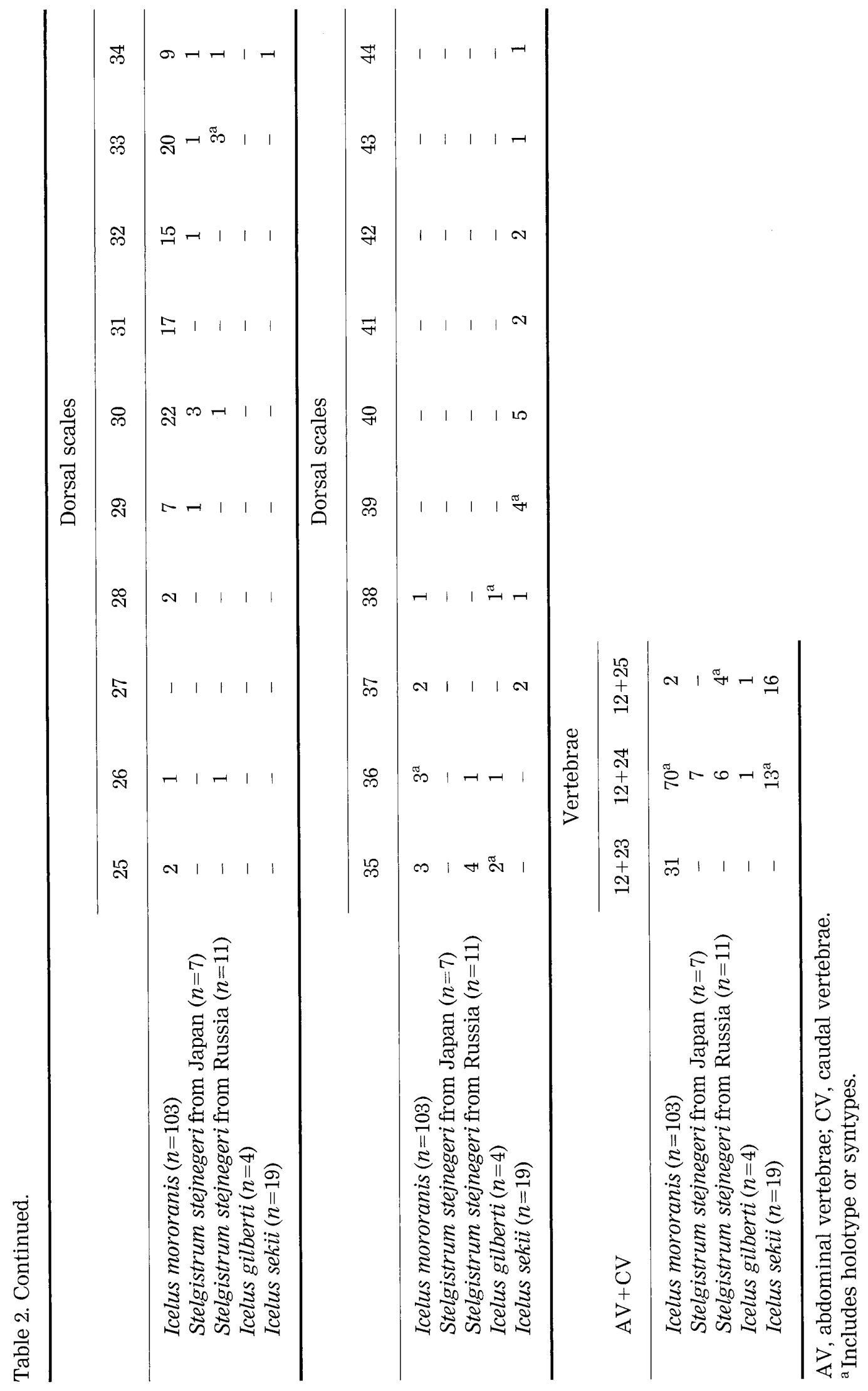


posteriorly. Dorsal scale row originating beneath second spine of first dorsal fin and extending to caudal peduncle. Small scales scattered above dorsal scale row and on spines and soft rays of dorsal fin. No scales between dorsal scale row and lateral line, nor below lateral line. One to three midsize scales scattered in pectoral axilla. Belly naked. Three pairs of cirri on dorsal surface of head. Unbranched cirrus on dorsal margin of eye. Two simple cirri on posterior end of maxilla. Small, simple cirrus on suborbital stay, another on posterior region of opercle. One small, simple cirrus on base of each preopercular spine and on several lateral-line scales.

First dorsal fin originating at level of dorsal edge of gill slit. First and second dorsal fins joined by low membrane; second dorsal fin originating above 12th lateral-line scale. Anal fin originating below origin of second dorsal fin. Pectoral fin large, rounded posteriorly. Pelvic fin slender, originating beneath second spine of first dorsal fin. Caudal fin slightly rounded. Anus located below ninth or 10th spine of first dorsal fin. Urogenital papilla of male absent.

Distribution. The present specimens were collected off Chirrip, Hamanaka, and off Atoeka, Kushiro, both in eastern part of Hokkaido, Japan, the western North Pacific (Fig. 3). This species is widely distributed in the Sea of Okhotsk from Tauiskaya Bay, the Shantar Islands, and the Jonas Island via the eastern coast of Sakhalin, Terpenie Bay, and Aniwa Bay to the western coast of Kamchatka and Iturup Island (Andriashev 1935; Schmidt 1950; Lindberg and Krasyukova 1987). In the Sea of Japan, it occurs along the coast of the Primorskii from the Tatar Strait to the Peter the Great Bay (Schmidt 1950; Lindberg and Krasyukova 1987; Sokolovskaya et al. 1998). In addition, it is known from the western coast of the Kuril Islands, the western North Pacific (Orlov 1998; Parin et al. 2002). Parin et al. (2002) recorded this species from depths of 18 to $320 \mathrm{~m}$.

Remarks. In order to consider the intra-specific variation of this species, nontype specimens collected from Russian Sea of Okhotsk were used as comparative material in addition to the holotype (see Appendix).

The seven specimens collected from off Atoeka and Chirrip in eastern Hokkaido are clearly assigned to Stelgistrum by the presence of four preopercular spines, teeth on jaws and vomer but not on palatines, scales with serrated margins forming the lateral-line scale row, enlarged scales each with serrated margin forming one dorsal scale row, and one spine and three soft rays in the pelvic fin (Andriashev 1935; Yabe 1985). Three species, S. stejnegeri, S. beringianum, and S. concinnum, are recognized in this genus. Stelgistrum stejnegeri is distinguishable from $S$. beringianum by having the dorsal scale row extending to the base of the caudal fin (not extending beyond the insertion of the second dorsal fin in S. beringianum), and scattered scales on the snout and cheek (vs such scales being absent or very few). It is also distinguishable from $S$. concinnum by having the maxilla extending nearly to the posterior edge of the eye (to the anterior edge of the eye in S. concinnum), no cirrus on the nasal spine (vs one unbranched cirrus there), and a single pair of nuchal cirri (vs two pairs).

The present seven specimens have all the diagnostic characters of $S$. stejnegeri mentioned above. In other morphological characters, they are also in complete agreement with the holotype of Stelgistrum stejnegeri (e.g., in the extent of scalecovered areas on the body). Their counts and proportional measurements coincide with, or are close to, those of the holotype and other specimens from the Russian side of the Sea of Okhotsk and Sea of Japan (Tables 1, 2). Thus, these seven speci- 
mens are identified as $S$. stejnegeri. No significant intra-specific variation was found between the present specimens and the comparative material.

Many authors have included Muroran in the distributional range of S. stejnegeri (Okada and Matsubara 1938; Schmidt 1950; Matsubara 1955; Watanabe 1958, 1960, 1978; Ueno 1971; Yabe 1984; Nakabo 1993, 2000, 2002). Except for Watanabe, these authors merely followed Jordan et al. (1913), who synonymized Stelgistrum mororanis under S. stejnegeri; their reports included no new topotypic specimens from Muroran. As was mentioned in the remarks under I. mororanis, S. stejnegri might have been included in Watanabe's studies, but his specimens are unavailable now. Thus the present report constitutes the first confirmed record of this species from Japanese waters.

\section{Acknowledgements}

We express our sincere thanks to Dr G. Shinohara (NSMT) for providing data on the holotype and information concerning the specimens owned by Dr Watanabe; Drs T. Iwamoto (CAS) and H. Imamura (Hokkaido University Museum; currently HUMZ) for providing data on the holotype; Prof. K. Nakaya (HUMZ) and Dr F. Muto (National Research Institute of Far Seas Fisheries) for their valuable suggestions on this study; and Dr H. Munehara (Usujiri Fisheries Station, Hokkaido University), Mr K. Seki (Shiretoko Diving Kikaku), and Mr N. Sato (Diving Service Grunt Sculpin) for their help in collecting specimens and for providing valuable information. We are also grateful to Dr A. J. Orr (Alaska Fisheries Science Center, NOAA) for critically reading the manuscript. This study was partly supported by a Grant-in-Aid for Science Research (No. 19570076) from the Japan Society for the Promotion of Science.

\section{Appendix: List of the Specimens Examined}

Icelus mororanis: SU 9260 at CAS (holotype), harbor of Muroran, Volcano Bay; HUMZ 201287, off Menashitomari, Esashi, Sea of Okhotsk; HUMZ 190078190080, 194919, 201285, 201286, off Oumu, Sea of Okhotsk; HUMZ 87725, off Lake Komuke, Sea of Okhotsk; HUMZ 188575, 190126-190129, off Rausu, eastern part of Hokkaido, northwestern Pacific; HUMZ 121684, 121717, 175832, 175833, 179894-179900, 179903-179906, 179908, 179910, 179913-179917, 185295-185302, 185304, 185305, 186672-186675, 186722, 186723, 187659-187662, 187824-187831, 187866-187892, 187894, 189778-189783, off Usujiri, Hakodate, northwestern Pacific; HUMZ 188567-188571, off Onagawa, Miyagi Prefecture, northwestern Pacific.

Stelgistrum stejnegeri collected from Japanese waters: HUMZ 92925, 92926, off Chirrip, Hamanaka, eastern part of Hokkaido, northwestern Pacific; HUMZ 201289-201293, off Atoeka, Kushiro, eastern part of Hokkaido, northwestern Pacific.

\section{Comparative specimens}

Icelus gilberti: ZISP 25514 (syntype), Olga Bay, Sea of Japan; ZISP 25328 (syntype), Vladimir Bay, Sea of Japan; HUMZ 87726, off Shokotsu, Sea of Okhotsk; HUMZ 
140590, off Lake Saroma, Sea of Okhotsk.

Icelus sekii: HUMZ 179901, 179902, 187896, 187897, 188572-188574, 198892, 198893, 200258 (incl. holotype and 3 paratypes), off Rausu, eastern part of Hokkaido; HUMZ 198857, off Shari, Shiretoko Peninsula, eastern part of Hokkaido, Sea of Okhotsk; HUMZ 187634, Moekeshi Bay, Iturup Island, Sea of Okhotsk; HUMZ 187898, 188505 (2 paratypes), off Urakawa, Hokkaido, northwestern Pacific; HUMZ 179892, 190688, 190689, 192091, 192092, off Usujiri, Hakodate, northwestern Pacific.

Stelgistrum stejnegeri: USNM 48236 (holotype), off Robben Island, Sea of Okhotsk; HUMZ 141143, off Feklistova Island, Sea of Okhotsk; HUMZ 140178, off Bolshoi Shantar Island, Sea of Okhotsk; HUMZ 140715, Severny Bay, Sakhalin, Sea of Okhotsk; SU 7577 at CAS, Aniwa Bay, Sakhalin, Sea of Okhotsk; SU 22324 at CAS (incl. 5 specimens), off western coast of Kamchatka, Sea of Okhotsk; ZISP 44166, Aniwa Bay, Sakhalin, Sea of Okhotsk.

\section{References}

Andriashev, A. P. 1935. Übersicht der Gattung Stelgistrum Jordan und Gilbert (Pisces, Cottidae) nebst Beschreibung einer neuen Art aus dem Beringmeer. Zoologischer Anzeiger 111: 289-297.

Böhlke, J. E. 1953. A catalogue of the type specimens of recent fishes in the Natural History Museum of the Stanford University. Stanford Ichthyological Bulletin 5: 1-168.

Eschmeyer, W. N. (Ed.) 1998. Catalog of Fishes, Vols 1-3. California Academy of Sciences, San Francisco, 2905 pp.

Fedorov, V. V., Chereshnev, I. A., Nazarkin, M. V., Shestakov, A. V. and Volobuev, V. V. 2003. Catalog of Marine and Freshwater Fishes of the Northern Part of the Sea of Okhotsk. Dalnauka, Vladivostok, 204 pp. [In Russian]

Hubbs, C. L. and Lagler, K. F. 1958. Fishes of the Great Lakes region. Bulletin of Cranbrook Institute of Science 26: 1-213.

Imamura, H. and Yabe, M. 2002. Demise of the Scorpaeniformes (Actinopterygii: Percomorpha): an alternative phylogenetic hypothesis. Bulletin of Fisheries Sciences, Hokkaido University 53: 107-128.

Jordan, D. S. and Gilbert, C. H. 1898. Stelgistrum, new genus. Pp. 1921-1922. In: Jordan, D. S. and Evermann, B. W. (Eds) The fishes of North and Middle America: a descriptive catalogue of the species of fish-like vertebrates found in the waters of North America, north of the Isthmus of Panama. Part II. Bulletin of the United States National Museum 47: i-xxiv $+1241-2183$.

Jordan, D. S. and Gilbert, C. H. 1899. The fishes of Bering Sea. Pp. 433-492, pls 43-85. In: Jordan, D. S. (Ed.) Fur Seals, and Fur-seal Islands of the North Pacific Ocean. Part III. Government Printing Office, Washington, D.C.

Jordan, D. S. and Seale, A. 1906. Descriptions of six new species of fishes from Japan. Proceedings of the United States National Museum 30: 143-148.

Jordan, D. S. and Starks, E. C. 1904. A review of the Cottidae or sculpins found in the waters of Japan. Proceedings of the United States National Museum 27: 231-335.

Jordan, D. S., Tanaka, S. and Snyder, J. O. 1913. A catalogue of the fishes of Japan. Journal of the College of Science, Imperial University of Tokyo 33: 1-497.

Lindberg, G. U. and Krasyukova, Z. V. 1987. Fishes of the Sea of Japan and Adjacent Parts of 
Okhotsk and Yellow Sea. Part 5. Teleostomi, Osteichthyes, Actinopterygii. 30 Scorpaeniformes (176. Fam. Scorpaenidae-194. Fam. Liparididae). Nauka SSSR, Leningrad, 526 pp. [In Russian]

Matsubara, K. 1955. Fish Morphology and Hierarchy. Part II. Ishizaki-shoten, Tokyo, xi-V+ 791-1377 pp. [In Japanese]

Mecklenburg, C. W., Mecklenburg, T. A. and Thorsteinson, L. K. 2002. Fishes of Alaska. American Fisheries Society, Bethesda, Maryland, xxxvii+1037 pp.

Nakabo, T. 1993. Cottidae. Pp. 548-567, 1300-1303. In: Nakabo, T. (Ed.) Fishes of Japan with Pictorial Keys to the Species (First Edition). Tokai University Press, Tokyo. [In Japanese]

Nakabo, T. 2000. Cottidae. Pp. 628-650, 1531-1534. In: Nakabo, T. (Ed.) Fishes of Japan with Pictorial Keys to the Species (Second Edition). Tokai University Press, Tokyo. [In Japanese]

Nakabo, T. 2002. Cottidae. Pp. 628 650, 1525-1528. In: Nakabo, T. (Ed.). Fishes of Japan with Pictorial Keys to the Species (English Edition). Tokai University Press, Tokyo.

Nelson, D. W. 1984. Systematics and distribution of cottid fishes of the genera Rastrinus and Icelus. Occasional Papers of the California Academy of Sciences 138: 1--52.

Okada, Y. and Matsubara, K. 1938. Keys to the Fishes and Fish-like Animals of Japan. Sanseido, Tokyo, xl+584 pp., 113 pls. [In Japanese]

Orlov, A. M. 1998. Demersal ichthyofauna of Pacific waters around the Kuril Islands and southeastern Kamchatka. Russian Journal of Marine Biology 24: 144-160.

Parin, N. N., Fedorov, V. V. and Sheiko, B. A. 2002. An annotated catalogue of fish-like vertebrates and fishes of the sea of Russia and adjacent countries. Part I. Order Scorpaeniformes. Journal of Ichthyology 42 (supplement 1): 60-135.

Popov, A. M. 1931. Zur Fischfauna des ochotskischen Meeres. Issledovanija Morey SSSR 14: 121-154. [In Russian with German summary]

Popov, A. M. 1933. Beiträge zur Ichthyofauna des japanischen Meeres. Issledovanija Morey SSSR 19: 139-155. [In Russian with German summary]

Schmidt, P. J. 1904. Pisces Marium Orientalium Imperii Rossici [Fishes of the Eastern Russian Empire]. Geograficheskogo Obshchestva, St. Petersburg, xi+466 pp., 6 pls. [In Russian]

Schmidt, P. Y. 1950. Ryby Okhotskogo Moray [Fishes of the Sea of Okhotsk]. Trudy Tikhookeanskogo Komiteta 6: 1-370, pls 1-20. [In Russian]

Sheiko, B. A. and Fedorov, V. V. 2000. Chapter 1. Class Cephalaspidomorphi-Lampreys. Class Chondrichthyes-Cartilaginous fishes. Class Holocephali-Chimaeras. Class Osteichthyes-Bony fishes. Pp. 7-69. In: Russian Academy of Sciences Far-Eastern Branch Kamchatka Institute of Ecology and Russian Academy of Sciences Zoological Institute (Eds) Catalog of the Vertebrates of Kamchatka and Adjacent Waters. Kamchatskiy Petchatniy Dvor, Petropavlovsk-Kamchatsky. [In Russian]

Sokolovskaya, T. G., Sokolovsky, A. S. and Sobolevsky, E. I. 1998. A list of fishes of the Peter the Great Bay (the Sea of Japan). Voprosy Ikhtiologii 38: 5-15. [In Russian]

Soldatov, V. K. and Lindberg, G. U. 1930. A review of the fishes of the seas of the Far East. Izvestiia Tikhookeanskogo Nauchnogo Instituta Rybnogo Khoziaistva 5: i-xlvii+ 1-576, pls 1-15. [In Russian with English summary and descriptions for new taxa]

Tanaka, S. 1933. Pisces. Pp. 74-350. In: Tanaka, S. (Ed.) Illustrated Book of Useful, Harmful, and Ornamental Fishery Animals-and-Plants. Daiichi-shoin, Tokyo. [In Japanese]

Taranetz, A. Y. 1937. Handbook for identification of fishes of Soviet Far East and adjacent waters. Izvestiia Tikhookeanskogo Nauchnogo Instituta Rybnogo Khoziaistva 11: 1-200+ map. [In Russian]

Taranetz, A. Y. 1941. On the classification and origin of the family Cottidae. Bulletin of the Academy of Sciences of U.S.S.R., Biological Series 3: 427-447. [In Russian with English 
summary]

Tsuruoka, O., Munehara, H. and Yabe, M. 2006. A new cottid species, Icelus sekii (Perciformes: Cottoidei), from Hokkaido, Japan. Ichthyological Research 53: 47-51.

Tsutsui, D. and Yabe, M. 1996. A new species of sculpin, Icelus ecornis (Scorpaeniformes: Cottidae) from the southwestern Okhotsk Sea. Ichthyological Research 43: 301-306.

Ueno, T. 1971. List of the marine fishes from the waters of Hokkaido and its adjacent regions. Scientific Report of the Hokkaido Fisheries Experimental Station 13: 61-102. [In Japanese with English summary]

Watanabe, M. 1958. Studies of the Cottid Fishes of Japan. Kadokawa-shoten, Tokyo, 461 pp., 124 pls. [In Japanese]

Watanabe, M. 1960. Fauna Japonica: Cottidae (Pisces). Tokyo News Service, Tokyo, vii+218 pp., 40 pls.

Watanabe, M. 1976. Studies on the sculpin of Japan and its adjacent waters (general part). Bulletin of the Watanabe Ichthyological Institute 1: 1-196, pls 1-41.

Watanabe, M. 1978. Studies on the sculpin of Japan and adjacent waters (special part). Bulletin of the Watanabe Ichthyological Institute 2: 197-418, pls 17-39.

Watanabe, M. 1980. Studies on the sculpin of Japan and adjacent waters (special part two). Bulletin of the Watanabe Ichthyological Institute 3: 419-478, pls 40-99.

Watanabe, M. 1981. Supplements to Fauna Japonica, Cottidae (1960). Bulletin of the Biogeographical Society of Japan 36: 102-131.

Yabe, M. 1983. Icelus mandibularis sp. nov. Pp. 282-285. In: Amaoka, K., Nakaya, K., Araya, H. and Yasui, T. (Eds) Fishes from the North-eastern Sea of Japan and the Okhotsk Sea off Hokkaido. Japan Fisheries Resource Conservation Association, Tokyo.

Yabe, M. 1984. Cottidae. Pp. 308-315. In: Masuda, H., Amaoka, K., Araga, C., Ueno, T. and Yoshino, T. (Eds) The Fishes of the Japanese Archipelago. Tokai University Press, Tokyo. [In Japanese]

Yabe, M. 1985. Comparative osteology and mycology of the superfamily Cottoidea (Pisces: Scorpaeniformes), and its phylogenetic classification. Memoirs of the Faculty of Fisheries, Hokkaido University 32: 1-130.

Yabe, M. 1991. Bolinia euryptera, a new genus and species of sculpin (Scorpaeniformes: Cottidae) from the Bering Sea. Copeia 1991: 329-339. 